\title{
Essential oils in Czech hop varieties
}

\author{
Vladimír Nesvadba ${ }^{{ }^{*}}$, Jana Olšovská2, Lenka Straková ${ }^{3}$, Jitka Charvátová ${ }^{1}$, Sabina Trnková ${ }^{1}$ \\ Hop Research Institute Co., Ltd., Saaz, Kadaňská 2525, 43801 \\ Žatec, Czech Republic \\ 2 Research Institute of Brewing and Malting, Lípová 15, 12044 \\ Prague, Czech Republic \\ Mendel University in Brno, Faculty of AgriSciences, Zemědělská \\ 1, 61300 Brno, Czech Republic \\ *Corresponding author: nesvadba@chizatec.cz
}

\begin{abstract}
Czech hop varieties were evaluated as part of maintenance breeding. The evaluation was performed in a single location between 2011 and 2020. The average weight of hop essential oils (HEOs) is 0.43 to $2.28 \%$ w/w. The Saaz, Saaz Brilliant, Mimosa, Saaz Shine and Saaz Comfort hop varieties have a low amount of HEOs. Their maximum content of these compounds amounts to $1.1 \% \mathrm{w} / \mathrm{w}$. The average proportion of myrcene is between 23.42 and $45.14 \%$ rel. Only the Agnus, Vital and Boomerang hop varieties have the maximum myrcene proportion above $50 \%$ rel. The average share of caryophyllene ranges between 6.19 and $13.15 \%$ rel. Saaz Late has a broad range of caryophyllene percentage - from $5.39 \%$ rel. to $15.53 \%$ rel. The average percenatge of farnesene is between 0.14 and $16.91 \%$ rel. Only the Saaz Comfort and Saaz Shine hop varieties have the maximum farnesene share above $20 \%$ rel. The average humulene content has a very broad range between 2.23 and 35.79\% rel. The Vital, Mimosa, Gaia and Saaz Comfort hop varieties are in a group with a low humulene percentage, which is clearly different from other hop varieties. The average share of selinenes ranges broadly from 0.97 to $33.56 \%$ rel. Mimosa differs from the before mentioned varieties with its proportion of selinenes between 23.08 and $43.75 \%$ rel. The aim was to characterize and compare Czech hop varieties in terms of content and composition of HEOs.
\end{abstract}

Key words: hop, Humulus lupulus L., hop essential oils, variability

\section{Introduction}

Historically, hop breeding in the Czech Republic has focused on fine aroma hops. The original local hop varieties, e.g. Saaz, Auscha, Klatovy and Tierschitz hops, were developed from the original populations of the individual locations. Hops from the Saaz and Auscha regions were given preference in the process of gradual selection. In the 1930s Karel Osvald, the founder of clonal selection in the Czech Republic, selected the best clones in these locations. The clonal selection concentrated on fine aroma hops, with a preference being given to the fine hoppy aroma. The results of recent chemical and genetic analyses of these clones show that they are very similar to the currently grown Osvald clones 31, 72 and 114 (Nesvadba et al., 2020a). In the 1960s, hybridisation was introduced to hop breeding, resulting in the registration of the Bor, Sládek and Premiant hop varieties in the 1990s. Between the years 2000 and 2020, a total of 12 hop varieties were registered for traditional hop fields and 3 hop varieties for low trellises (Blues, Country and Jazz). Currently, hop breeding focuses on hops with special flavours, i.e. flavour hops (Nesvadba et al., 2020b).

The content and composition of hop resins and hop essential oils (HEOs) are evaluated from a beer brewing perspective. HEOs are crucial in terms of the hop aroma. Depending on the hop variety, the content of HEOs ranges from 0.3 to $3.0 \% \mathrm{w} / \mathrm{w}$ (Nesvadba et al., 2013). Both HEOs and hop resins synthesize in lupulin glands during the formation and ripening of hop cones. The components of HEOs are divided into three groups. The hydrocarbon fraction has the largest share, accounting for $70-80 \%$ of the total weight of HEOs. Oxygen and sulphur fractions fall into the other two groups. The sulphur fraction accounts 
for only $1 \%$ of the weight of HEOs. However, these are sensorily very active substances, and therefore their impact on the overall hop aroma is not negligible (Rettberg et al., 2018). The content and composition of HEOs have a genetic basis. Therefore, the origin of a hop variety can be determined on the basis of the content and composition of HEOs (Olšovská et al., 2016). For example, isobutyl isobutyrate, 2-methylbutyl isobutyrate and 3-methyl isobutyrate can be found in Saaz Late but not in Saaz. Therefore, it is easy to differentiate between Saaz Late and Saaz (Krofta and Patzak, 2011a). HEOs are also very important for the individual beer styles (Zainasheff and Palmer, 2007).

Hop varieties are characterized by yield, resistance to disease and pests, sensitivity to agrotechnological interventions as well as by the content and composition of hop resins and HEOs (Nesvadba et al., 2020a). The performance of hop varieties depends on these characteristics. However, another crucial attribute is the stability of quantitative and qualitative parameters. The lack of precipitation in the last few years has had a negative impact on the quantity and quality of hop varieties (Krofta et al., 2019; Krofta et al., 2020). Therefore, a research project QK21010136 entitled "Application of new hop varieties and genotypes resistant to drought in hop growing and beer brewing" was launched in 2021. The evaluation of stability during the growing period is essential for breweries. A lack of precipitation is naturally the only parameter influencing the stability of these characteristics. The evaluation does not focus on the influence of weather on the content and composition of HEOs. Its objective is to evaluate the stability of these two parameters in Czech hop varieties. It is of great importance to brewers to know which hop varieties show a stable or, in contrast, a non-stable content and composition of HEOs.

\section{Material and methods}

The hop varieties were evaluated as part of maintenance breeding at the Hop Research Institute in Žatec, which is the owner of the tested Czech hop varieties. All evaluated hop varieties are grown in a single location, i.e. in a hop field in Stekník near Žatec under standard operating conditions. The hop samples were collected from at least 40 plants of each hop variety.

\section{Evaluated hop varieties:}

1. Fine aroma hops with the content of alpha acids from 2.5 to $5.5 \%$, with a balanced alpha/ beta ratio and a fine hoppy aroma - Saaz, Saaz Late, Saaz Brilliant, Saaz Comfort and Saaz Shine.

2. Aroma hop varieties with the content of alpha acids from 3.5 to $8.5 \%$, with an alpha/beta ratio ranging between 1 and 2 and a hoppy aroma Bor, Sládek, Premiant, Harmonie and Bohemie.

3. Bittering varieties with the content of alpha acids from 8 to $14 \%$, with an alpha/beta ratio ranging between 2 and 3 and a strong hoppy (and sometimes even spicy) aroma - Agnus, Rubín, Vital, Gaia and Boomerang.

4. Hop varieties with a special flavour (flavour hops), which have aromas such as citrusy, fruity, herbal and woody - Kazbek and Mimosa.

Hop cones were harvested in the state of technological ripeness and dried at the temperature of $55-60{ }^{\circ} \mathrm{C}$. Shortly before the analyses, dry hop cones are grinded. HEOs are isolated by using a distillation method. The content of HEOs is determined as a share of the weight volatilised during a 90-minute boil from $100 \mathrm{~g}$ of hops. (Krofta, 2008). The composition of HEOs was analysed by using gas chromatography with a DB 5 column $(30 \mathrm{~m} \times 0.25 \mathrm{~mm} \times 0.50 \mathrm{~mm})$ with a temperature program ranging from $60^{\circ} \mathrm{C}$ to $250{ }^{\circ} \mathrm{C}$ (Krofta, 2002) and the THERMO-FOCUS gas chromatograph in connection with the DSQ II weight detector.

The following basic statistics were prepared: average (x) and standard deviation (s). Relative amount of variability is applied to compare a set with different levels. Resulting variability amounts are dimensionless numbers mostly in \%. This makes it possible to compare the variability of statistical parameters differing in measure units. Coefficient of variation (CV), showing the extent of variability in $\%$, was used for data processing (Meloun, 1994).

\section{Results and discussion}

Figure 1 shows the values of the minimum, average and maximum content of HEOs. The average content of HEOs ranges from $0.43 \% \mathrm{w} / \mathrm{w}$ (Saaz) to $2.28 \% \mathrm{w} / \mathrm{w}$ (Boomerang). The Saaz, Saaz Brilliant, Mimosa, Saaz Shine and Saaz Comfort hop varieties have a low concentration of HEOs, with maximum values of HEO amounting to $1.1 \%$ w/w. In contrast, Harmonie, Sládek, Agnus, Gaia and Boomerang show a maximum portion of HEOs above $2 \% \mathrm{w} / \mathrm{w}$. The Atlas of Czech Hop Varieties (Nesvadba et al., 2012) states that the content of HEOs in Saaz ranges from 0.4 to $0.8 \% \mathrm{w} / \mathrm{w}$. The results achieved are at the lower limit. In the Bor hop variety, they are even below the range specified by the authors, i.e. from 1.2 to $2.0 \%$ $\mathrm{w} / \mathrm{w}$. The Agnus hop variety with a specified range of the content of HEOs between 2.0 and $3.0 \% \mathrm{w} / \mathrm{w}$ is also below the limit. The content of HEOs above $2 \% \mathrm{w} / \mathrm{w}$ was found in this variety during six years (2011, 2015, 2016 and 2018-2020). 
As shown in Figure 2, the average content of myrcene below $25 \%$ rel. was found in Saaz Brilliant $(23.42 \%$ rel.), Saaz Shine (23.55\% rel.) and Saaz (24.37\% rel.). In contrast, Vital and Boomerang have an average proportion of myrcene above $24 \%$ rel. $(40.18 \%$ rel. and $45.14 \%$ rel., respectively). The minimum and maximum percentage of myrcene makes it possible to draw a clear dividing line between the hop varieties. These limits overlap, i.e. the maximum share of myrcene in Saaz Brilliant (30.94\% rel.) is higher than the minimum share of myrcene in Boomerang (23.86\% rel.). However, Saaz Brilliant, Saaz Shine, Saaz, Premiant, Saaz Comfort and Bor do not exceed the limit of maximum proportion of myrcene of $30 \%$ rel. Only the high-alpha hop varieties such as Agnus, Vital and Boomerang have a maximum share of myrcene above $50 \%$ rel.

The average percentage of caryophyllene in Czech hop varieties ranges between $6.19 \%$ rel. (Mimosa) and $13.15 \%$ rel. (Sládek). Based on the minimum and maximum values, the hop varieties can be divided into 3 groups (Figure 3 ). The maximum share of caryophyllene in Mimosa and Saaz is lower than the minimum share in Premiant, Gaia, Agnus and Sládek. The remaining Czech hop varieties are positioned between these two groups, with minimum and maximum values falling into both groups. Saaz Late has a broad range of caryophyllene content - from the minimum of $5.39 \%$ rel. to the maximum of $15.53 \%$ rel. In contrast, Mimosa shows the smallest range - between 4.83 and $7.57 \%$ rel.

A higher percentage of farnesene is one of the characteristics of Saaz hops. Figure 4 shows that only Saaz and the hop varieties derived from it (Saaz Late, Saaz Brilliant, Saaz Shine and Saaz Comfort) have the average farnesene proportion of more than $10 \%$ rel. Saaz Comfort has the highest farnesene share (16.91\% rel.). The maximum content of farnesene above $20 \%$ rel. was found in Saaz Comfort and Saaz Shine only. Bohemie, Premiant, Vital and Gaia show the farnesene share above $1 \%$ rel. In some years, Bor, Agnus and Mimosa had the farnesene proportion of more than $1 \%$ rel. as well. Other hop varieties have the farnesene share below $1 \%$ rel. The results show that hop varieties with a lower percentage have a higher variability. Saaz Late and Saaz have their farnesene amount at the lower limit specified in the Atlas of Czech hop varieties (Nesvadba et al., 2012). The content of farnesene in the new fine aroma hops - Saaz Brilliant, Saaz Comfort and Saaz Shine - is almost identical with the results achieved in hop breeding evaluations. Nesvadba et al. (2020b) specify that the share of farnesene in Saaz Brilliant ranges from 7 to $14 \%$ rel., in Saaz Comfort between 2 and 14\% rel. and in Saaz Shine between 7 and $20 \%$ rel. 
The content of humulene in Czech hop varieties shows a broad variability (Figure 5). Vital, Mimosa, Gaia and Saaz Comfort represent a group with a low proportion of humulene, which is different from other hop varieties. The maximum content of these varieties does not exceed $10 \%$ rel. A very low percentage of humulene in Vital was also specified by Krofta et al. (2011b). The second group has an average humulene share ranging from $18.57 \%$ rel. (Saaz Late) to $35.79 \%$ rel. (Bor). The results show that the minimum and maximum values of these hop varieties overlap. The broadest range of humulene was found in Saaz Late (from 12.41 to $37.13 \%$ rel.) and Agnus (between 14.11 and $36.52 \%$ rel.).

As shown in Figure 6, the lowest average proportion of selinenes was detected in Boomerang $(0.97 \%$ rel.) and the highest average proportion in Mimosa (33.56\% rel.). Czech hop varieties can be divided into several groups based on the percentage of selinenes. The selinene content in Boomerang, Saaz, Sládek, Bor, Saaz Shine, Premiant, Agnus, Kazbek, Saaz Brilliant and Saaz Late is below $10 \%$ rel. Saaz Comfort, Harmonie, Vital, Rubín and Gaia with the share of selinenes between 10 and $30 \%$ rel. fall into the second group. The Bohemie hop variety with the selinene share ranging from $8.38 \%$ rel. to $12.84 \%$ rel. is positioned between these two groups. Mimosa with the abundance of selinenes between $23.08 \%$ rel. and $43.75 \%$ rel. is very different. It is remarkable to observe that the Saaz Comfort fine aroma hops have a higher percentage of selinenes than other Saaz-series hops (Saaz, Saaz Late, Saaz Brilliant and Saaz Shine). The significantly higher content of selinenes in Saaz Comfort is a differentiable
Figure 3 Share and variability of caryophyllene in Czech hop varieties (Stekník, maintenance breeding, 2011-2020)

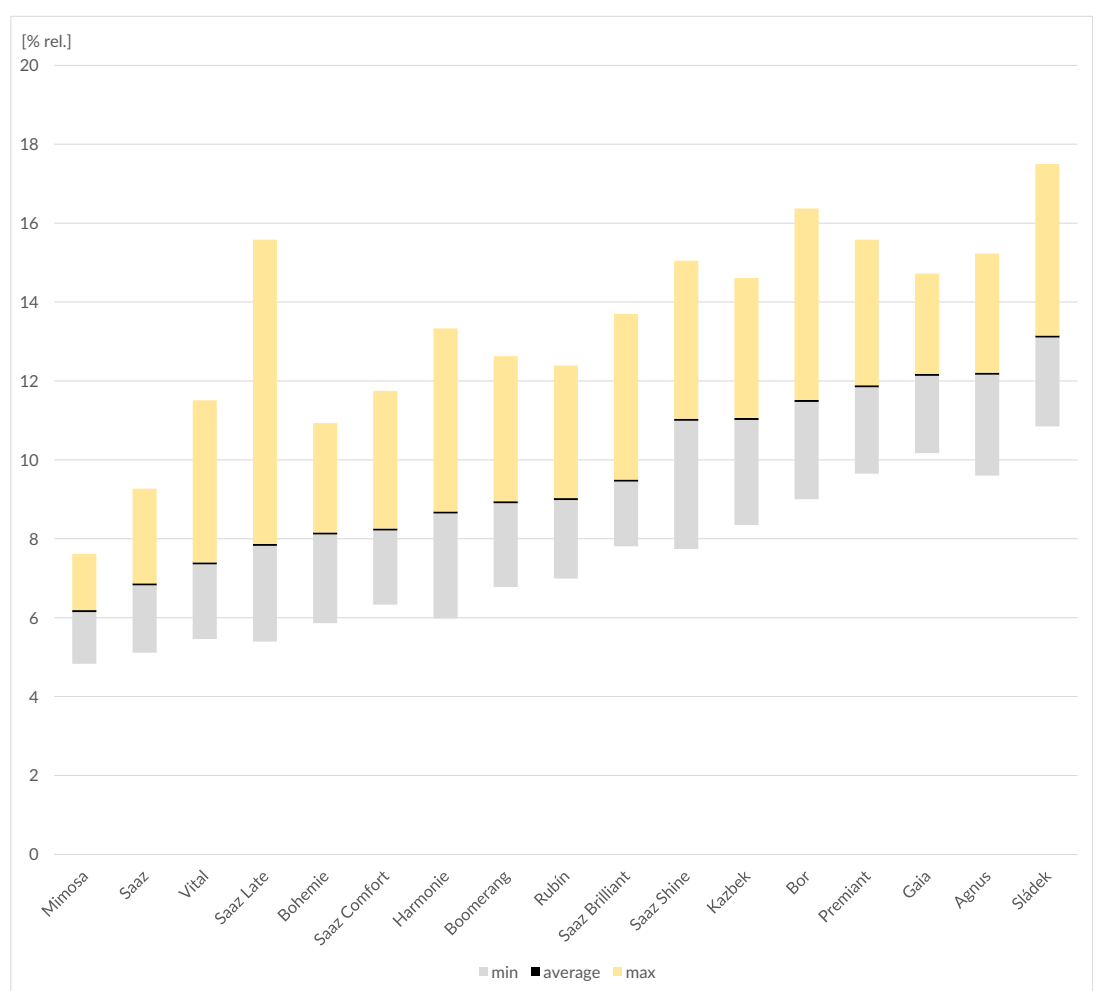

Figure 4 Share and variability of farnesene in Czech hop varieties (Stekník, maintenance breeding, 2011-2020)

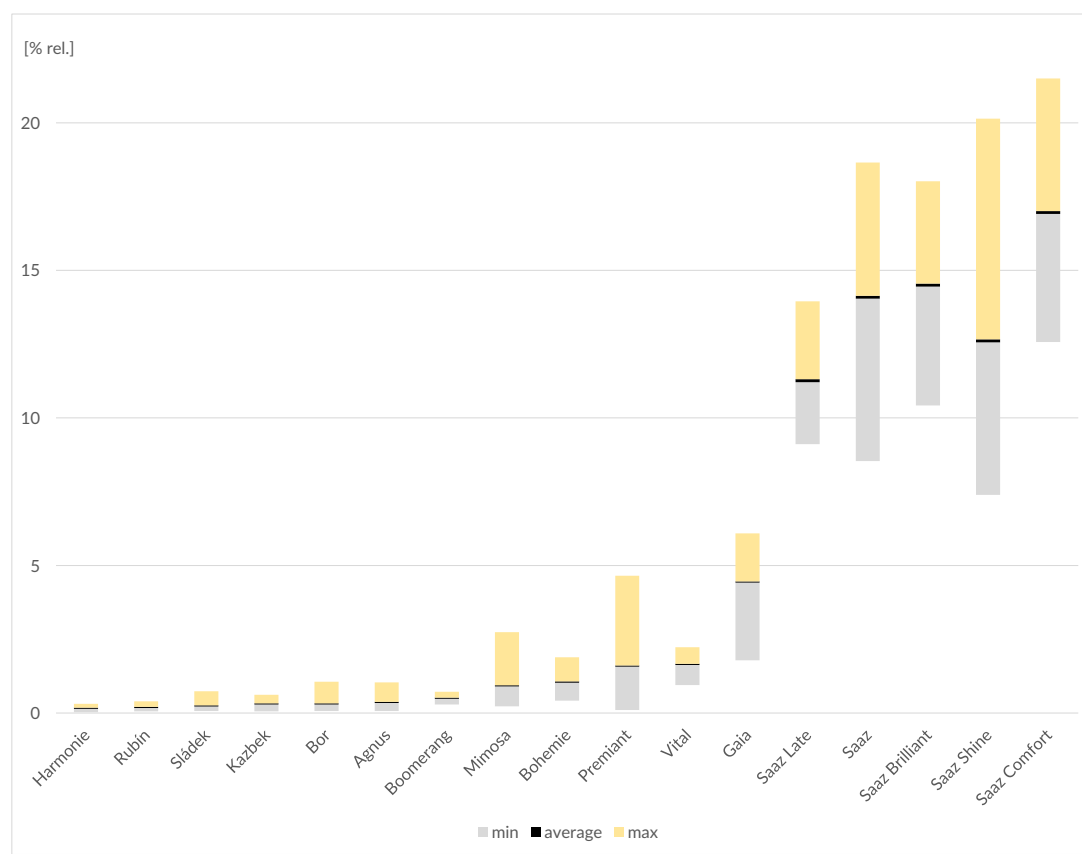

characteristic among these hop varieties. The share of selinenes presented in publications corresponds with the results achieved. For example, Krofta et al. (2009) specify that the Harmonie hop variety has a selinene share rang- 
ing from 10 to $19 \%$ rel. A higher proportion of selinenes in Saaz Late compared to Saaz is confirmed by Mikyška et al. (2013), who specifies the selinene share between 3 and $5 \%$ rel.

The summary table shows the average weight and share of HEOs in Czech hop varieties (Table 1). The Gaia, Vital, Saaz Comfort and Mimosa hop varieties are characterised by a higher percentage of myrcene and selinenes and (in contrast) a low humulene share. The Saaz Comfort hop variety has a higher farnesene content. A very high myrcene proportion and simultaneously a higher humulene content are typical for Boomerang. The highest percentage of humulene was found in Premiant and Bor. These two hop varieties are not very different in the composition of HEOs. Mimosa has the highest share of selinenes and a very low share of caryophyllene, farnesene and humulene. Vital and Saaz Comfort show a low portion of humulene as well. Saaz has a lower share of myrcene, caryophyllene and selinenes and a higher proportion of farnesene and humulene. The Saaz Late, Saaz Brilliant and Saaz Shine hop varieties have a similar composition of HEOs. Rubín and Kazbek are characterised by a medium share of myrcene, a higher share of caryophyllene and humulene and a low content of farnesene and selinenes. Harmonie and Bohemie have
Figure 5 Share and variability of humulene in Czech hop varieties (Stekník, maintenance breeding, 2011-2020)

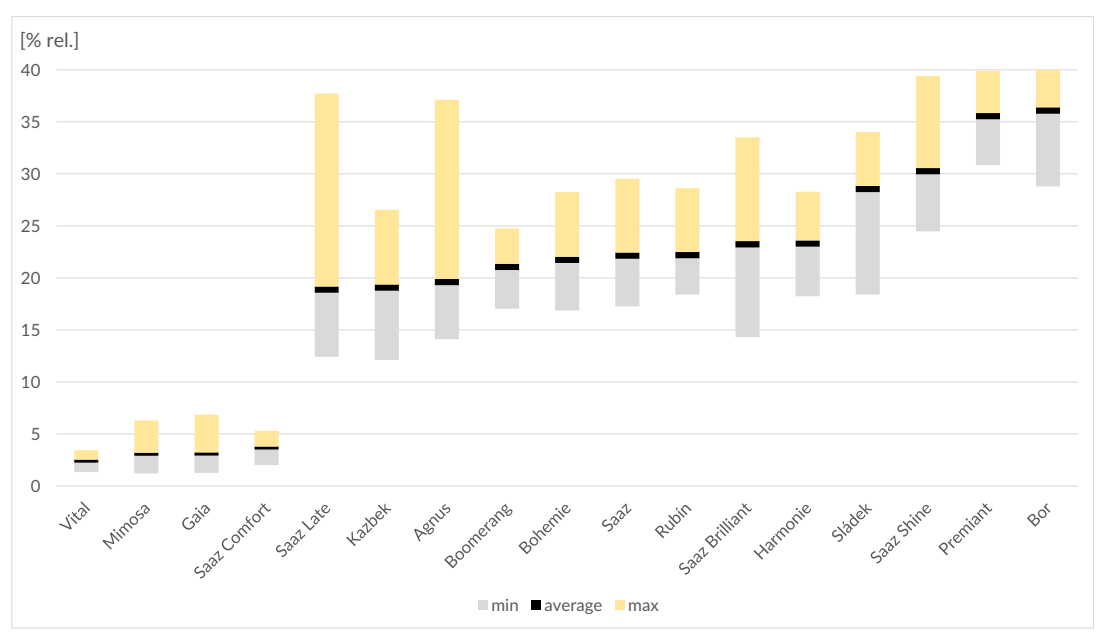

Figure 6 Share and variability of selinenes in Czech hop varieties (Steknik, maintenance breeding, 2011-020)

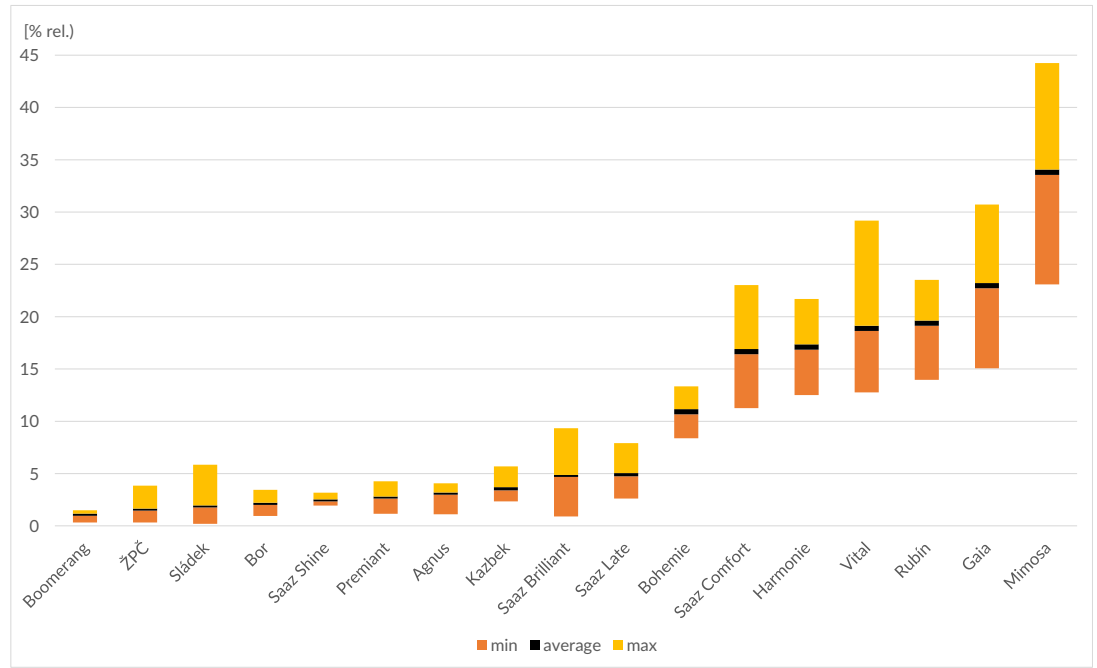

a similar composition of HEOs with only one difference - they have a higher share of selinenes. The results show a broad variability in the content and composition of HEOs in Czech hop varieties. 
Table 1 Average content and composition of hop essential oils (HEOs) in Czech hop varieties (Stekník, maintenance breeding, 2011-2020)

\begin{tabular}{|c|c|c|c|c|c|c|}
\hline Variety & $\begin{array}{c}\text { Weight } \\
(\mathbf{g} / 100 \mathrm{~g})\end{array}$ & $\begin{array}{c}\text { Myrcene } \\
\text { (\% rel.) }\end{array}$ & $\begin{array}{c}\text { Caryophyllene } \\
\text { (\% rel.) }\end{array}$ & $\begin{array}{c}\text { Farnesene } \\
\text { (\% rel.) }\end{array}$ & $\begin{array}{c}\text { Humulene } \\
\text { (\% rel.) }\end{array}$ & $\begin{array}{c}\text { Selinenes } \\
\text { (\% rel.) }\end{array}$ \\
\hline Boomerang & 2.28 & 45.14 & 8.95 & 0.48 & 20.75 & 0.97 \\
\hline Gaia & 1.97 & 35.40 & 12.18 & 4.42 & 2.92 & 22.72 \\
\hline Agnus & 1.83 & 33.45 & 12.21 & 0.34 & 19.30 & 2.99 \\
\hline Sládek & 1.52 & 30.18 & 13.15 & 0.22 & 28.24 & 1.76 \\
\hline Harmonie & 1.49 & 31.15 & 8.69 & 0.14 & 23.00 & 16.85 \\
\hline Vital & 1.43 & 40.18 & 7.40 & 1.63 & 2.23 & 18.63 \\
\hline Rubín & 1.23 & 27.27 & 9.03 & 0.17 & 21.89 & 19.13 \\
\hline Kazbek & 1.13 & 34.93 & 11.06 & 0.29 & 18.76 & 3.40 \\
\hline Premiant & 1.12 & 26.97 & 11.89 & 1.57 & 35.25 & 2.61 \\
\hline Bohemie & 1.04 & 29.18 & 8.16 & 1.03 & 21.44 & 10.67 \\
\hline Bor & 0.92 & 28.41 & 11.52 & 0.29 & 35.79 & 2.01 \\
\hline Saaz Late & 0.83 & 31.28 & 7.87 & 11.21 & 18.57 & 4.75 \\
\hline Saaz Comfort & 0.81 & 28.11 & 8.26 & 16.91 & 3.49 & 16.41 \\
\hline Saaz Shine & 0.72 & 23.55 & 11.04 & 12.56 & 29.96 & 2.34 \\
\hline Mimosa & 0.67 & 30.55 & 6.19 & 0.90 & 2.89 & 33.56 \\
\hline Saaz Brilliant & 0.50 & 23.42 & 9.50 & 14.45 & 22.93 & 4.68 \\
\hline Saaz & 0.43 & 24.37 & 6.87 & 14.04 & 21.84 & 1.46 \\
\hline
\end{tabular}

The Saaz Late, Saaz Brilliant, Saaz Comfort and Saaz Shine hop varieties were developed from Saaz as the mother variety. They are fine aroma hops with a similar composition of HEOs. Figure 7 shows that Saaz Comfort is different because of a higher percentage of selinenes and a lower percentage of humulene. Saaz Shine shows a higher amount of humulene than the other hop varieties. The content of myrcene, caryophyllene and farnesene is almost identical in all of these hop varieties.

Table 1 was used to convert the weight of the individual components of HEOs in relation to the weight of HEOs in $1 \mathrm{~kg}$ of hops (Table 2). The Boomerang variety contains $22.75 \mathrm{~g}$ of HEOs in $1 \mathrm{~kg}$ of hops. Bor, Saaz Late, Saaz Shine, Mimosa, Saaz Brilliant and Saaz are below $10 \mathrm{~g}$ of HEOs. It is very interesting to examine the amount of the individual HEO components in $1 \mathrm{~kg}$ of hops. Boomerang has the highest weight of myrcene $10.37 \mathrm{~g} / \mathrm{kg}$. Gaia, Agnus and Vital show a weight of myrcene above $5 \mathrm{~g} / \mathrm{kg}$. In contrast, Bor, Saaz Late, Saaz Comfort, Saaz Shine, Mimosa, Saaz Brilliant and Saaz have a myrcene content below $3 \mathrm{~g} / \mathrm{kg}$. All hop varieties with the highest myrcene proportion (except Vital) simultaneously have the highest content of caryophyllene. Sládek also has a caryophyllene amount exceeding $2 \mathrm{~g} / \mathrm{kg}$. At the same time, it shows a very high amount of humulene $(4.30 \mathrm{~g} / \mathrm{kg})$ and selinenes $(2.84 \mathrm{~g} / \mathrm{kg})$. The farnesene content is remarkable. As assumed, the highest quantity of farnesene was found in Saaz and several Saaz-derived hop varieties. However, Gaia also has a high weight of HEOs $(0.87 \mathrm{~g} / \mathrm{kg})$ thanks to a high portion of HEOs and a medium share of farnesene. Only the Boomerang, Agnus, Sládek, Harmonie, Premiant and Bor hop varieties amount humulene above $3 \mathrm{~g} / \mathrm{kg}$. The most abundant selinenes was found in Gaia (4.49 g/kg). The Harmonie, Vital, Rubín and Mimosa varieties amount selinenes of more than $2 \mathrm{~g} / \mathrm{kg}$.

Figure 7 Composition of hops essential oils (HEOs) in the Saaz varietal series (Stekník, maintenance breeding, 2011-2020)

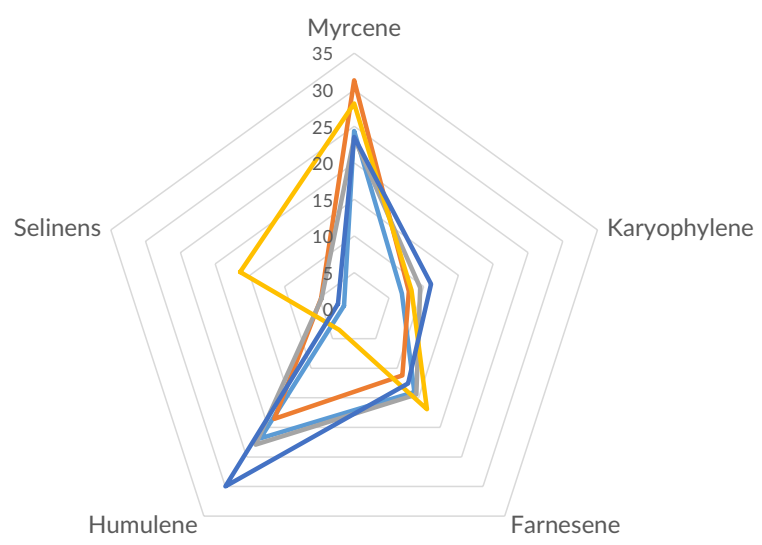

—Saaz — Saaz Late —Saaz Brilliant —Saaz Comfort — Saaz Shine 
Table 2 Weight of total hop essential oils (HEOs) and the individual components of HEOs in $1 \mathrm{~kg}$ of hops (Stekník, maintenance breeding, 2011-2020)

\begin{tabular}{|c|c|c|c|c|c|c|}
\hline & $\begin{array}{l}\text { Weight } \\
\text { (g/kg) }\end{array}$ & $\begin{array}{c}\text { Myrcene } \\
(\mathrm{g} / \mathrm{kg})\end{array}$ & $\begin{array}{c}\text { Caryophyllene } \\
\text { (g/kg) }\end{array}$ & $\begin{array}{l}\text { Farnesene } \\
(\mathrm{g} / \mathrm{kg})\end{array}$ & $\begin{array}{l}\text { Humulene } \\
\qquad(\mathrm{g} / \mathrm{kg})\end{array}$ & $\begin{array}{l}\text { Selinenes } \\
\text { (g/kg) }\end{array}$ \\
\hline Boomerang & 22.75 & 10.27 & 2.04 & 0.11 & 4.72 & 0.22 \\
\hline Gaia & 19.74 & 6.99 & 2.41 & 0.87 & 0.58 & 4.45 \\
\hline Agnus & 18.34 & 6.14 & 2.24 & 0.06 & 3.54 & 0.55 \\
\hline Sládek & 15.23 & 4.60 & 2.00 & 0.03 & 4.30 & 0.27 \\
\hline Harmonie & 14.91 & 4.64 & 1.30 & 0.02 & 3.43 & 2.51 \\
\hline Vital & 14.31 & 5.75 & 1.06 & 0.23 & 0.32 & 2.67 \\
\hline Rubín & 12.27 & 3.35 & 1.11 & 0.02 & 2.69 & 2.35 \\
\hline Kazbek & 11.31 & 3.95 & 1.25 & 0.03 & 2.12 & 0.38 \\
\hline Premiant & 11.21 & 3.02 & 1.33 & 0.18 & 3.95 & 0.29 \\
\hline Bohemie & 10.43 & 3.04 & 0.85 & 0.11 & 2.24 & 1.11 \\
\hline Bor & 9.17 & 2.61 & 1.06 & 0.03 & 3.28 & 0.18 \\
\hline Saaz Late & 8.28 & 2.59 & 0.65 & 0.93 & 1.54 & 0.39 \\
\hline Saaz Comfort & 8.09 & 2.27 & 0.67 & 1.37 & 0.28 & 1.32 \\
\hline Saaz Shine & 7.15 & 1.68 & 0.79 & 0.90 & 2.14 & 0.16 \\
\hline Mimosa & 6.68 & 2.04 & 0.41 & 0.06 & 0.19 & 2.24 \\
\hline Saaz Brilliant & 5.04 & 1.18 & 0.48 & 0.73 & 1.16 & 0.24 \\
\hline Saaz & 4.27 & 1.04 & 0.29 & 0.60 & 0.93 & 0.06 \\
\hline
\end{tabular}

\section{Conclusion}

Hop varieties from a single location are evaluated within a time span of 10 years. This naturally limits the influence of the environment, and therefore the results are only influenced by a genotype and a year. However, hop growing locations in the Czech Republic are variable, and therefore some publications can present different results of measurements and evaluations of Czech hop varieties. The objective is to gain an overview of the variability in the composition of HEOs in Czech hop varieties, which would be relevant to beer brewing. Over the past few years, late-boil hopping has been increasingly used to gain the necessary hop aroma which comes from HEOs. The amount of added HEO components can have a major impact on the resulting beer aroma desirable for a particular brewery or a beer style.

The results show that hop varieties differ in their content of HEOs. However, it is necessary to convert the share to HEO weight. Then, it becomes apparent that some hop varieties with a different proportion of HEOs and their weight can provide the same amount of certain HEOs to beer. For example the Gaia hop variety has the same farnesene weight as Saaz. If this relationship was taken into account during hopping, for which alpha acid content is decisive, Gaia would be used three times less frequently than Saaz and other hop varieties. However, this perspective is remarkable for applying hops in the whirlpool and for dry-hopping, since these are not related to alpha acids. The results achieved by us do not represent recommendations for breweries. Every brewery needs to consider the use of HEOs according to their needs and their approach, i.e. based on which HEO components they do or do not wish to utilize and for which method of hopping or beer style they use a certain hop variety, and therefore give preference to a high (or low) content of individual HEO components.

\section{Acknowledgement}

The study was supported by the Ministry of Agriculture of the Czech Republic within the institutional support MZe-R01918 and MZE-R01320.

\section{References}

Krofta, K. (2008). Hodnocení kvality chmele: Metodika pro praxi 4/2008. (eng. Evaluation of hop quality: Methodology for practice 4/2008.) Hop Research Institute, Ltd., Žatec, 52 pp. ISBN 978-80-86836-843 Available in Czech from: https://invenio.nusl.cz/record/170477/ files/nusl-170477_1.pdf

Krofta, K. (2002). Obsah a složení chmelových pryskyřic žateckých chmelů z pohledu jejich pivovarské hodnoty (eng. Content and composition of hop resins of Saaz hops from the point of view of their brewing value). Thesis, University of Chemical Technology, Prague. Available only in Czech.

Krofta, K., Nesvadba, V., Mikyška, A., Hašková, D. (2009). Harmonie - Czech aroma hop variety. Kvasny prumysl, 55(7-8), 170-176. https://doi. org/10.18832/kp2009017 
Krofta, K., Patzak, J. (2011a). Investigation of Czech Hop Varieties Authenticity by Means of Chemical and Genetic Analyses. Kvasny prumysl, 57(7-8), 296-304. https://doi.org/10.18832/kp2011035

Krofta, K., Nesvadba, V., Patzak, J. (2011b). Vital - new Czech hop variety. Proceedings of Scientific Commission of IHGC, Lublin, Poland, June 19-23, 19.

Krofta, K., Klapal, I., Vojtěchová, D., Ondráček, J., Kroupa, F., Tichá, J. (2019). Hodnocení kvalitativních parametrů českých chmelů ze sklizně 2018 (eng. Evaluation of qualitative parameters of Czech hops from the harvest of 2018). Chmelařství, 92(1-2), 2-11. Available only in Czech.

Krofta K., Vojtěchová D., Tichá J. (2020). Hodnocení kvalitativních parametrů českých chmelů ze sklizně 2019 (eng. Evaluation of qualitative parameters of Czech hops from the harvest of 2019). Chmelařství, 1-2/2020, 7-15. Available only in Czech.

Meloun, M., Militký, J. (1994). Statistické zpracování experimentálních dat (eng. Statistical processing of experimantal data). Plus, Praha, 839 p. Available in Czech from: ucebnice1994.pdf (upce.cz).

Mikyška, A., Slabý, M., Jurková, M., Krofta, K., Patzak, J., Nesvadba, V. (2013). Saaz Late - The Czech Hop Variety Recommended for Czech Beer. Kvasny prumysl, 59(10-11), 296-305. https://doi.org/10.18832/kp2013031

Nesvadba, V., Polončíková, Z., Henychová, A., Krofta, K., Patzak, J. (2012). Atlas of Czech hop varieties. Chmelařský institut s.r.o., Žatec. ISBN 978-80-87357-11-8 Available from: http://invenio.nusl.cz/record/161364/files/nusl-161364_1.pdf
Nesvadba, V., Brynda, M., Henychová, A., Ježek, J., Kořen, J., Krofta, K., Malířová, I., Patzak, J., Polončíková, Z., Svoboda, P., Valeš, V., Vostřel, J. (2013). Development and tradition of Czech hop varieties. Hop Research Institute, CO., LTD., Žatec, 91 pp.

Nesvadba, V., Charvátová, J., Henychová, A., Patzak, J. (2020a). Evaluation of original historical clones of hops (Humulus lupulus L.). Kvasny prumysl, 66(6), 382-391. https://doi.org/10.18832/kp2019.66.382

Nesvadba, V., Charvátová, J., Trnková, S. (2020b). Breeding of flavour hops in the Czech Republic. Kvasny prumysl, 66(6), 366-371. https://doi. org/10.18832/kp2019.66.366

Olšovská, J., Krofta, K., Jandovská, V., Patzak J., Štěrba, K. (2016). Methods for verifying the authenticity of hops - an effective tool against falsification. Kvasny prumysl, 62(10), 294-305. https://doi. org/10.18832/kp2016030

Rettberg, N., Biendl, M., Garbe, L.-A. (2018). Hop Aroma and Hoppy Beer Flavor: Chemical Backgrounds and Analytical Tools - A Review. Journal of the American Society of Brewing Chemists, 76(1), 1-20. https://doi.org/10.1080/03610470.2017.1402574

Zainasheff, J., Palmer, J. (2007). Brewing classic styles. Brewers Publications, 17-21. ISBN 0937381926 